\title{
SKILL CAPABILITY AMONG LIS PROFESSIONALS IN DEVELOPING DISTRICTS OF TAMIL NADU: A STUDY
}

\section{S. RAVI}

Dean, School of Communication, Professor and Head, Department of Library and Information Science,

Central University of Tamil Nadu, Thiruvarur, Tamil Nadu, India

The fast-changing social, economic, and technology environments will continue to drive organisations to seek professionals with skills to meet with user needs. This study examines nearly 15 criteria across the spectrum of Appraisal, Views on enriching, Inquisitiveness, Key Requirements, Visible Vision and Online medium among library and information science professionals. This study carried out to identify the Key Requirements for professional skill and to identify the Inquisitiveness in developing the skill. Further the impact of Infrastructure environment and work environment in developing the skill were also identified. This study was carried out among 210 LIS professionals of 76 engineering institutions in 8 districts (Ariyalur, Cuddalore, Nagapattinam, Perambalur, Thanjavur, Tiruvannamalai, Tiruvarur, and Villupuram) under the affiliation of Anna University. Out of 210 distributed 157 responded. The response rate works out to $74.76 \%$. The Professionals aware that there exist Challenges towards skill development and they are aware that it is essential to develop a Skill Capacity in the changing technological environment.

KEYWORDS: Skill Development, The Key Requirement in Skill, Online Medium, Inquisitiveness, Appraisal \& Views on Enriching
\end{abstract}

Received: Sep 24, 2018; Accepted: Oct 15, 2018; Published: Nov 01, 2018; Paper Id.: IJLSRDEC20181

\section{INTRODUCTION}

The fast-changing social, economic, and technology environments will continue to drive organisations to seek professionals with skills to meet with customers; work in fluid, matrixes, and other complex environments. It is essential to accommodate evolving organizational cultures and the rapid introduction of new tools and approaches to successfully perform "work". A number of major megatrends will drive organisational needs:

- Increasingly diverse customer base

- Employee's relationship with employer.

- Increased complexity of business structures and organizations

- Expanding mobile customers and increased electronic communication.

- Increasing economic importance of digital commerce and digital content

- $\quad$ TT in the workplace 


\section{RELATED STUDIES}

To provide information that suits user demands, information literacy, communication, critical thinking, and teamwork are the most required generic skills. In this digital era, the representative of a new generation of LIS professionals should be a person who is able to act as facilitator or mentor to help the user to find the information needed and to evaluate it.

Few of the skills such as Information Skills (Pintos, Molina 2008, Walter 2008, Dell -Price and Cotton 2008), Information Literacy Skills (Ramesh Babu 2011, Ramesh Babu \& Nageswara Rao 2011, Hagland and Herson 2008), ICT skills (Thomas and Rulter 2008,Owvia, Bada \& Aimbonam 2006), Soft Skills (Harris 2007) are the need of the day. Regarding personal qualities/characteristics of professionals, Bergman (1992), Kaufman (1994), Sherman et al (1998), Sanghi (2004), Deb (2006) and Opatha (2007,2009), have emphasized that many types of personal qualities/characteristics are necessary for professionals. Further the necessity of interpersonal, intrapersonal and problem solving skill has been realized by the LIS professionals. (Balakrishnan et al., 2014)

\section{SAMPLE}

The questionnaires were distributed to the Library and Information Science professionals of 76 engineering institutions. Nearly 210 questionnaires were distributed. Out of 210 distributed 157 responded. The response rate works out to $74.76 \%$.

\section{Demographic Details}

The demographic details of the respondents were shown in the Table 1.

Table 1: Demographic Details

\begin{tabular}{|c|c|c|c|}
\hline S. No & Description & \multicolumn{2}{|c|}{ Respondents } \\
\hline \multicolumn{4}{|c|}{ District } \\
\hline 1 & Ariyalur & 10 & $6.4 \%$ \\
\hline 2 & Cuddalore & 16 & $10.2 \%$ \\
\hline 3 & Nagapattinam & 16 & $10.2 \%$ \\
\hline 4 & Perambalur & 16 & $10.2 \%$ \\
\hline 5 & Thanjavour & 25 & $15.9 \%$ \\
\hline 6 & Thiruvannamalai & 24 & $15.3 \%$ \\
\hline 7 & Thiruvarur & 6 & $3.8 \%$ \\
\hline 8 & Villupuram & 44 & $28.0 \%$ \\
\hline \multicolumn{4}{|c|}{ Gender } \\
\hline 1 & Male & 94 & $59.9 \%$ \\
\hline 2 & Female & 63 & $40.1 \%$ \\
\hline \multicolumn{4}{|c|}{ Designation } \\
\hline 1 & Librarian & 121 & $77.1 \%$ \\
\hline 2 & Asst. Librarian & 18 & $11.45 \%$ \\
\hline 3 & Others & 18 & $11.45 \%$ \\
\hline \multicolumn{4}{|c|}{ Overall } \\
\hline & Total & 157 & $100.0 \%$ \\
\hline
\end{tabular}


SKILL

The skill has been ascertained based 15 variables on six categories such as Appraisal, Views on enriching, Inquisitiveness, Key Requirements, Visible Vision and Online medium.

\section{Appraisal}

Appraisal on self sufficiency of academic skill has been ascertained among the respondents to indicate "not sufficient" and "Sufficient". The opinions thus obtained were shown district-wise, gender-wise and designation-wise along with overall in the Table 2.

Table 2: Appraisal

\begin{tabular}{|c|c|c|c|c|c|c|c|}
\hline \multirow{2}{*}{ S. No } & \multirow{2}{*}{ Districts } & \multicolumn{2}{|c|}{ Not Sufficient } & \multicolumn{2}{|c|}{ Sufficient } & \multicolumn{2}{|c|}{ Total } \\
\hline & & Response & $\%$ & Response & $\%$ & Response & $\%$ \\
\hline \multicolumn{8}{|c|}{ Districts } \\
\hline 1 & Ariyalur & 2 & $20.0 \%$ & 8 & $80.0 \%$ & 10 & $6.4 \%$ \\
\hline 2 & Cuddalore & 4 & $25.0 \%$ & 12 & $75.0 \%$ & 16 & $10.2 \%$ \\
\hline 3 & Nagapattinam & 4 & $25.0 \%$ & 12 & $75.0 \%$ & 16 & $10.2 \%$ \\
\hline 4 & Perambalur & 4 & $25.0 \%$ & 12 & $75.0 \%$ & 16 & $10.2 \%$ \\
\hline 5 & Thanjavour & 5 & $20.0 \%$ & 20 & $80.0 \%$ & 25 & $15.9 \%$ \\
\hline 6 & Thiruvannamalai & 4 & $16.7 \%$ & 20 & $83.3 \%$ & 24 & $15.3 \%$ \\
\hline 7 & Thiruvarur & 1 & $16.7 \%$ & 5 & $83.3 \%$ & 6 & $3.8 \%$ \\
\hline 8 & Villupuram & 11 & $25.0 \%$ & 33 & $75.0 \%$ & 44 & $28.0 \%$ \\
\hline \multicolumn{8}{|c|}{ Gender } \\
\hline 1 & Male & 21 & $22.3 \%$ & 73 & $77.7 \%$ & 94 & $100.0 \%$ \\
\hline 2 & Female & 14 & $22.2 \%$ & 49 & $77.8 \%$ & 63 & $100.0 \%$ \\
\hline \multicolumn{8}{|c|}{ Designation } \\
\hline 1 & Librarian & 26 & $16.6 \%$ & 95 & $60.5 \%$ & 121 & $77.0 \%$ \\
\hline 2 & Asst. Librarian & 6 & $3.8 \%$ & 12 & $7.6 \%$ & 18 & $11.5 \%$ \\
\hline 3 & Others & 3 & $1.9 \%$ & 15 & $9.6 \%$ & 18 & $11.5 \%$ \\
\hline \multicolumn{8}{|c|}{ Overall } \\
\hline & Total & 35 & $22.3 \%$ & 122 & $77.7 \%$ & 157 & 100.00 \\
\hline
\end{tabular}

Out of 157 respondents, $122(77.7 \%)$ indicated that the academic skill were sufficient. Only $35(22.3 \%)$ indicated not sufficient. It can be seen from the table 4.6 that the sufficiency of the academic skill district-wise ranges between $75.0 \%$ and $83.3 \%$ indicated that academic skill was sufficient. In the case of insufficiency, it ranges between $16.7 \%$ and $25.0 \%$. Therefore, it can be inferred that the academic skill were indicated sufficient for capability assessment.

Out of 94 males, $73(77.7 \%)$ indicated that academic skill was sufficient, whereas only $21(22.3 \%)$ indicated it is not sufficient. Similarly out of 63 females, 49 (77.8\%) female indicated sufficient and only 14 (22.2\%) indicated not sufficient.

Out of $121(77.1 \%)$, Librarians, $95(50.5 \%)$ indicated that academic skill was sufficient, whereas only $26(16.6 \%)$ indicated it is not sufficient. In the case of Asst. Librarian, out of 18, 12 (7.6\%) of Asst. librarian indicated sufficient and only $6(3.8 \%)$ indicated not sufficient. Similarly out of 18 other library professionals, $15(9.6 \%)$ indicated sufficient and only $3(1.9 \%)$ indicated not sufficient. 


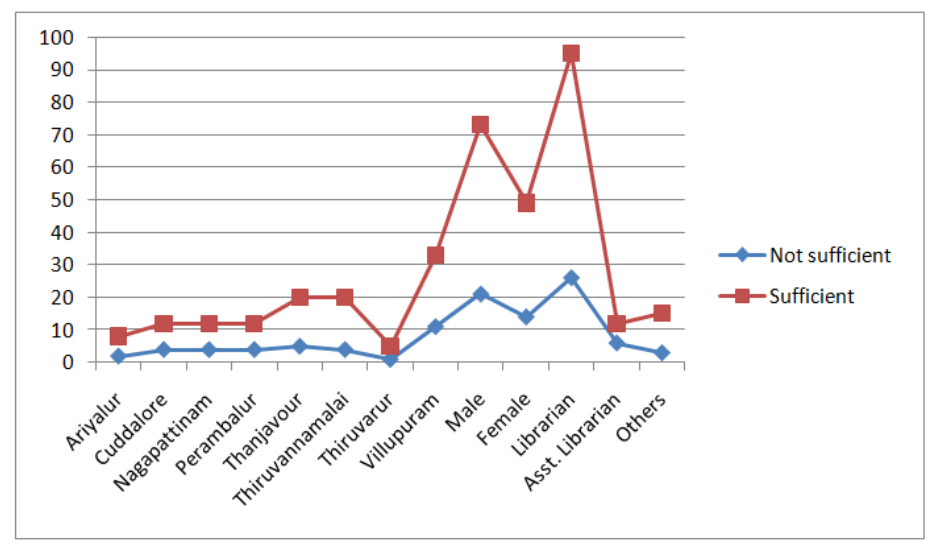

Figure 1: Appraisal

\section{Enrich}

The views on enriching the skill has been ascertained based on two variables on a five point scale such as "Poor", "Average", "Satisfactory", "good" and "very good" from the respondents. The mean and standard deviation were calculated based on the opinion. The ranks were ascertained based on mean and standard deviation. The variables, respondents' opinion, mean, standard deviation and rank were shown in the Table 3

Table 3: Views on Enriching the Skill

\begin{tabular}{|c|c|c|c|c|c|c|c|c|c|c|c|c|c|c|}
\hline S. No & Description & \multicolumn{2}{|c|}{ Poor } & \multicolumn{2}{|c|}{ Average } & \multicolumn{2}{|c|}{ Satisfactory } & \multicolumn{2}{|c|}{ Good } & \multicolumn{2}{|c|}{ Very Good } & Mean & Std & Rank \\
\hline 1 & willing to learn & 36 & $22.9 \%$ & 65 & $41.4 \%$ & 52 & $33.1 \%$ & 4 & $2.5 \%$ & 0 & $.0 \%$ & 2.15 & .802 & 1 \\
\hline 2 & Facility to learn & 42 & $26.8 \%$ & 63 & $40.1 \%$ & 46 & $29.3 \%$ & 4 & $2.5 \%$ & 2 & $1.3 \%$ & 2.11 & .877 & 2 \\
\hline
\end{tabular}

The mean value of the two variables on views on library curriculum ranges works out to 2.11 and 2.15respectively, which indicates that they lie towards average. The standard deviation works out to 0.802 and 0.877 which indicates that there has been no deviation of opinion.

The first preference was given for "Willing to learn". It is followed by "Present Curriculum". The mean, standard deviation and rank among district, gender, and designation were compared with overall mean value and the same has been shown in the Table 4.

Table 4: Views on Enriching the Skill -District, Gender and Designation-wise

\begin{tabular}{|l|l|c|c|c|c|c|c|}
\hline \multirow{2}{*}{ S. No } & \multirow{9}{*}{ Districts } & \multicolumn{3}{c|}{ Willing to Learn } & \multicolumn{3}{c|}{ Facility to Learn } \\
\cline { 3 - 8 } & & Mean & Std. & Rank & Mean & Std & Rank \\
\hline \multicolumn{8}{|c|}{ District } \\
\hline 1 & Ariyalur & 2.50 & .707 & 1 & 2.20 & .789 & 3 \\
\hline 2 & Cuddalore & 1.75 & .683 & 7 & 1.63 & .619 & 8 \\
\hline 3 & Nagapattinam & 2.25 & 1.000 & 3 & 2.19 & .911 & 4 \\
\hline 4 & Perambalur & 2.19 & .750 & 5 & 2.44 & 1.153 & 1 \\
\hline 5 & Thanjavour & 2.12 & .781 & 6 & 2.00 & .764 & 6 \\
\hline 6 & Thiruvannamalai & 2.25 & .737 & 2 & 2.42 & .974 & 2 \\
\hline 7 & Thiruvarur & 1.67 & .516 & 8 & 1.67 & .516 & 7 \\
\hline 8 & Villupuram & 2.20 & .851 & 4 & 2.09 & .830 & 5 \\
\hline \multicolumn{7}{|c|}{ Gender } \\
\hline 1 & Male & 2.16 & .766 & 1 & 2.14 & .859 & 2 \\
\hline 2 & Female & 2.14 & .859 & 2 & 2.22 & 1.039 & 1 \\
\hline \multicolumn{7}{|c|}{ Designation } \\
\hline
\end{tabular}




\begin{tabular}{|c|l|c|c|c|c|c|c|}
\hline \multicolumn{1}{|c|}{ Table 4: Contd., } \\
\hline 1 & Librarian & 2.12 & .787 & 3 & 2.04 & .831 & 3 \\
\hline 2 & Asst. Librarian & 2.22 & .943 & 2 & 2.17 & .857 & 2 \\
\hline 3 & Others & 2.33 & .767 & 1 & 2.56 & 1.097 & 1 \\
\hline & \multicolumn{1}{|c|}{ Total } & $\mathbf{2 . 1 5}$ & $\mathbf{. 8 0 2}$ & & $\mathbf{2 . 1 1}$ & $\mathbf{. 8 7 7}$ & \\
\hline
\end{tabular}

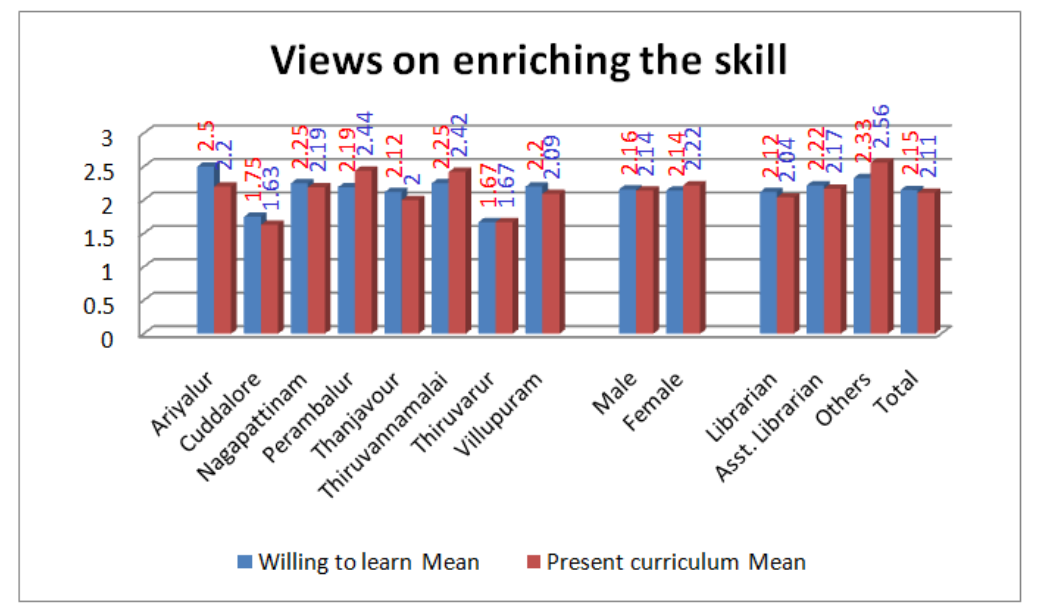

Figure 2: Views on Library Curriculum Vs Demographic details

In the case of male, the mean value ranges works out to 2.14 and 2.16 respectively which indicate that the respondents' opinion leans towards Average to satisfactory the variables where as the mean value of female ranges between 2.14 and 2.22. The mean value indicates that there were no much deviation in respondents' opinion among male and female. The preferences among male were "Willing to learn" and "Present curriculum itself sufficient". In the case of female the preference female were get interchanged.

The Asst. Librarian of designation domain respondents' mean value works out to 2.17 and 2.22 which indicates that the respondents opinion lean towards average to satisfactory to the variables. The mean value of Librarians between 2.04 and 2.12 which indicates that there exist identical opinion as like that of Asst. Librarian with little bit less confidence than Asst. Librarian. Similarly the mean value of other library professionals ranges between 2.33 and 2.56 which indicates the opinion lies head of Asst. Librarian and Librarian. The preferences were identical among Librarian and Asst. Librarian whereas in the case of other library professionals the order gets interchanges.

In the case of districts, for the variable "willing to learn", the mean value ranges between 1.67 and 2.50 which indicate that the respondent's opinion leans towards average and satisfactory whereas the mean value of the variable "Present curriculum" ranges between 1.63 and 2.44. The mean value indicates that there were no much deviation in eight district respondents' opinion on the variables "Willing to learn" and "Present curriculum". There exist similar preferences among the different districts, except Perambalur and Thiruvannamalai since the order of preferences interchanged. It is surprise to note that equal preference was indicated by Thiruvarur respondents.

\section{Inquisitiveness}

The inquisitiveness has been ascertained based on five variables Evaluation skill; Assessment Skill; communication skill; Interpersonal skill and Intrapersonal skill on a five point scale such as Poor; Average; Satisfactory; good and very good from the respondents. The mean and standard deviation were calculated based on opinion. The ranks were ascertained based on mean and standard deviation. The variables, respondents' opinion, mean, standard 
deviation and rank were shown in the Table 5.

Table 5: Inquisitiveness

\begin{tabular}{|c|c|c|c|c|c|c|c|c|c|c|c|c|c|c|}
\hline \multirow{2}{*}{$\frac{\text { S. No }}{1}$} & \multirow{2}{*}{$\begin{array}{c}\text { Description } \\
\text { Evaluation skill }\end{array}$} & \multicolumn{2}{|c|}{ Poor } & \multicolumn{2}{|c|}{ Average } & \multicolumn{2}{|c|}{ Satisfactory } & \multicolumn{2}{|c|}{ Good } & \multicolumn{2}{|c|}{$\begin{array}{l}\text { Very } \\
\text { Good }\end{array}$} & \multirow{2}{*}{$\frac{\text { Mean }}{2.10}$} & \multirow{2}{*}{$\begin{array}{l}\text { Std } \\
.846\end{array}$} & \multirow{2}{*}{$\frac{\text { Rank }}{4}$} \\
\hline & & 41 & $26.1 \%$ & 68 & $43.3 \%$ & 40 & $25.5 \%$ & 8 & $5.1 \%$ & 0 & $.0 \%$ & & & \\
\hline 2 & Assessment Skill & 36 & $22.9 \%$ & 51 & $32.5 \%$ & 52 & $33.1 \%$ & 9 & $5.7 \%$ & 9 & $5.7 \%$ & 2.39 & 1.078 & 2 \\
\hline 3 & communication skill & 2 & $1.3 \%$ & 8 & $5.1 \%$ & 14 & $8.9 \%$ & 82 & $52.2 \%$ & 51 & $32.5 \%$ & 4.10 & .853 & 1 \\
\hline 4 & Interpersonal skill & 44 & $28.0 \%$ & 73 & $46.5 \%$ & 40 & $25.5 \%$ & 0 & $.0 \%$ & 0 & $.0 \%$ & 1.97 & .733 & 5 \\
\hline 5 & Intrapersonal skill & 36 & $22.9 \%$ & 54 & $34.4 \%$ & 50 & $31.8 \%$ & 8 & $5.1 \%$ & 9 & $5.7 \%$ & 2.36 & 1.069 & 3 \\
\hline
\end{tabular}

The mean value all the five inquisitiveness variables range between 1.97 and 2.39 which indicates that they lie between average and satisfactory. The standard deviation range between 0.733 and 1.078 which indicates that there has been no deviation on opinion.

The first preference was given to "Communication skill". It is followed by "Assessment skill" and "Intrapersonal skill". The least preference was indicated to "Interpersonal skill"; mean value was 1.96 each which indicates that the respondents have average inquisitiveness to the variables.

Table 6: Inquisitiveness Vs District

\begin{tabular}{|c|c|c|c|c|c|c|c|c|c|c|c|c|c|c|c|c|}
\hline \multirow{2}{*}{ S. No } & \multirow[b]{2}{*}{ Districts } & \multicolumn{3}{|c|}{ Evaluation skill } & \multicolumn{3}{|c|}{ Assessment Skill } & \multicolumn{3}{|c|}{ communication skill } & \multicolumn{3}{|c|}{ Interpersonal skill } & \multicolumn{3}{|c|}{ Intrapersonal skill } \\
\hline & & Mean & Std. & Rank & Mean & Std. & Rank & Mean & Std. & Rank & Mean & Std. & Rank & Mean & Std. & Rank \\
\hline \multicolumn{17}{|c|}{ DISTRICTS } \\
\hline 1 & Ariyalur & 2.40 & .699 & 1 & 2.40 & .699 & 4 & 3.90 & 1.197 & 6 & 2.20 & .789 & 1 & 2.40 & .699 & 5 \\
\hline 2 & Cuddalore & 1.88 & .957 & 7 & 2.63 & 1.360 & 1 & 4.31 & .602 & 2 & 1.63 & .619 & 8 & 2.50 & 1.414 & 2 \\
\hline 3 & Nagapattinam & 2.06 & .772 & 4 & 2.06 & .772 & 8 & 4.19 & .834 & 4 & 2.06 & .772 & 4 & 2.06 & .772 & 8 \\
\hline 4 & Perambalur & 2.06 & .772 & 4 & 2.38 & 1.147 & 5 & 4.25 & .683 & 3 & 2.06 & .727 & 3 & 2.50 & 1.095 & 1 \\
\hline 5 & Thanjavour & 2.20 & .957 & 3 & 2.56 & 1.158 & 2 & 3.88 & .881 & 7 & 1.88 & .726 & 6 & 2.48 & 1.194 & 3 \\
\hline 6 & Thiruvannamalai & 2.38 & .875 & 2 & 2.50 & .978 & 3 & 3.83 & .917 & 8 & 2.08 & .717 & 2 & 2.46 & .977 & 4 \\
\hline 7 & Thiruvarur & 1.33 & .516 & 8 & 2.33 & 1.751 & 6 & 4.67 & .516 & 1 & 1.67 & .516 & 7 & 2.17 & 1.472 & 7 \\
\hline 8 & Villupuram & 2.02 & .792 & 6 & 2.27 & 1.042 & 7 & 4.16 & .861 & 5 & 2.02 & .762 & 5 & 2.27 & 1.042 & 6 \\
\hline \multicolumn{17}{|c|}{ GENDER } \\
\hline 1 & Male & 2.05 & .896 & 4 & 2.33 & 1.140 & 2 & 4.10 & .868 & 1 & 1.98 & .733 & 5 & 2.32 & 1.119 & 3 \\
\hline 2 & Female & 2.16 & .766 & 4 & 2.48 & .981 & 2 & 4.10 & .837 & 1 & 1.97 & .740 & 5 & 2.43 & .995 & 3 \\
\hline \multicolumn{17}{|c|}{ DESIGNATION } \\
\hline 1 & Librarian & 2.13 & .865 & 4 & 2.44 & 1.110 & 2 & 4.08 & .881 & 1 & 1.97 & .730 & 5 & 2.40 & 1.100 & 3 \\
\hline 2 & Asst. Librarian & 1.94 & .802 & 5 & 1.94 & .802 & 5 & 4.17 & .786 & 1 & 2.06 & .725 & 3 & 2.17 & .786 & 2 \\
\hline \multirow[t]{2}{*}{3} & Others & 2.00 & .767 & 4 & 2.50 & 1.043 & 2 & 4.11 & .758 & 1 & 1.94 & .802 & 5 & 2.28 & 1.127 & 3 \\
\hline & Total & 2.10 & .846 & 4 & 2.39 & 1.078 & 2 & 4.10 & .853 & 1 & 1.97 & .733 & 5 & 2.36 & 1.069 & 3 \\
\hline
\end{tabular}




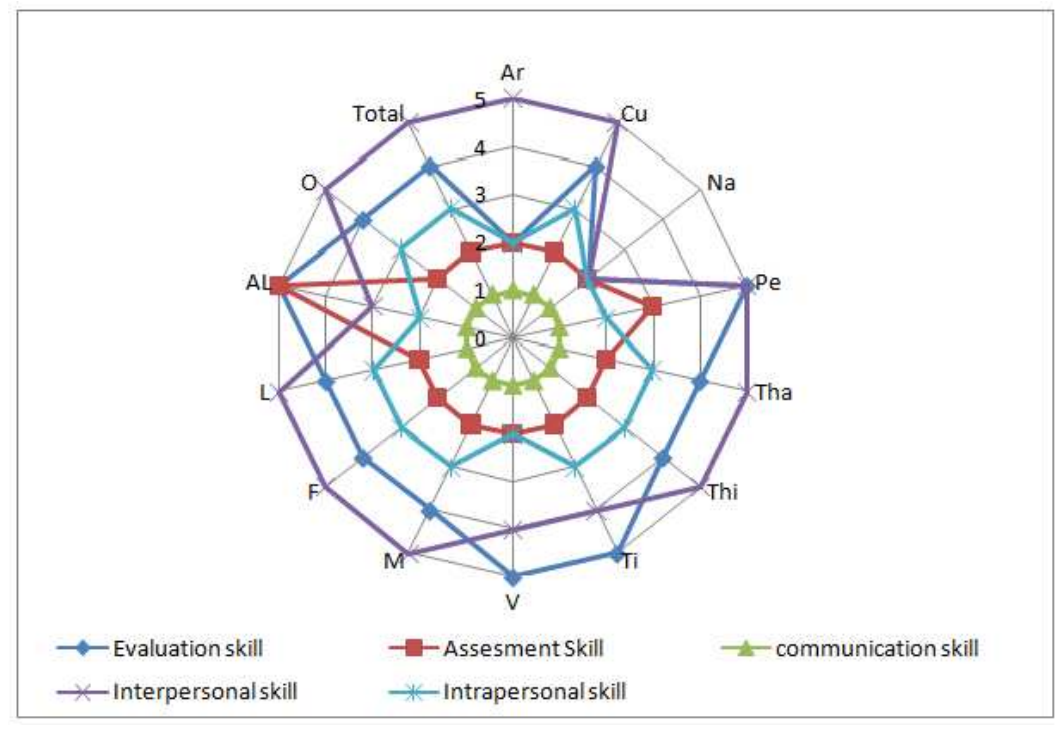

Figure 3: Inquisitiveness vs. Overall Rank

\section{Key Requirements}

The key requirements has been ascertained based on the five variables such as Analytical skills; Relevant work experience; Updated knowledge; Ability to understand, learn quickly and easily, and Novel approach and creativeness, on a five point scale such as Strongly disagree; Disagree; No opinion; Agree Strongly and Agree from the respondents. The mean and standard deviation were calculated based on the opinion. The ranks were ascertained based on the mean and standard deviation. The variables, respondents' opinion, mean, standard deviation and rank were shown in the Table 7

Table 7: Key Requirements

\begin{tabular}{|c|c|c|c|c|c|c|c|c|c|c|c|c|c|c|}
\hline \multirow{2}{*}{ S. No } & \multirow{2}{*}{$\begin{array}{l}\text { Description } \\
\text { Analytical skills }\end{array}$} & \multicolumn{2}{|c|}{$\begin{array}{l}\text { Strongly } \\
\text { Disagree }\end{array}$} & \multicolumn{2}{|c|}{ Disagree } & \multicolumn{2}{|c|}{ No Opinion } & \multicolumn{2}{|c|}{ Agree } & \multicolumn{2}{|c|}{$\begin{array}{l}\text { Strongly } \\
\text { Agree }\end{array}$} & \multirow{2}{*}{$\begin{array}{c}\text { Mean } \\
3.91 \\
\end{array}$} & \multirow{2}{*}{$\frac{\text { Std }}{1.190}$} & \multirow{2}{*}{$\frac{\text { Rank }}{3}$} \\
\hline & & 9 & $5.7 \%$ & 16 & $10.2 \%$ & 16 & $10.2 \%$ & 55 & $35.0 \%$ & 61 & $38.9 \%$ & & & \\
\hline 2 & Relevant work experience & 8 & $5.1 \%$ & 14 & $8.9 \%$ & 20 & $12.7 \%$ & 52 & $33.1 \%$ & 63 & $40.1 \%$ & 3.94 & 1.162 & 2 \\
\hline 3 & Updated knowledge & 10 & $6.4 \%$ & 11 & $7.0 \%$ & 15 & $9.6 \%$ & 53 & $33.8 \%$ & 68 & $43.3 \%$ & 4.01 & 1.179 & 1 \\
\hline 4 & $\begin{array}{l}\text { Ability to understand, } \\
\text { learn quickly and easily }\end{array}$ & 16 & $10.2 \%$ & 15 & $9.6 \%$ & 25 & $15.9 \%$ & 54 & $34.4 \%$ & 47 & $29.9 \%$ & 3.64 & 1.281 & 4 \\
\hline 5 & $\begin{array}{l}\text { Novel approach and } \\
\text { creativeness }\end{array}$ & 19 & $12.1 \%$ & 15 & $9.6 \%$ & 24 & $15.3 \%$ & 49 & $31.2 \%$ & 50 & $31.8 \%$ & 3.61 & 1.343 & 5 \\
\hline
\end{tabular}

The mean value of all the five inquisitiveness variables range between 3.61 and 4.01 which indicate that they lie between agree and strongly agree. The standard deviation range between 1.179 and 1.343 which indicates that there has been no deviation on opinion.

The first preference was given for "Updated knowledge". It is followed by "Relevant work experience" and “Analytical skills". The least preference was indicated to "Novel approach and creativeness". 
Table 8: Key Requirements Vs District

\begin{tabular}{|c|c|c|c|c|c|c|c|c|c|c|c|c|c|c|c|c|}
\hline \multirow[t]{2}{*}{ S. No } & \multirow[t]{2}{*}{ Districts } & \multicolumn{3}{|c|}{ Analytical Skills } & \multicolumn{3}{|c|}{ Relevant Work Experience } & \multicolumn{3}{|c|}{ Updated Knowledge } & \multicolumn{3}{|c|}{$\begin{array}{l}\text { Ability to Understand, } \\
\text { Learn Quickly and Easily }\end{array}$} & \multicolumn{3}{|c|}{ Novel Approach } \\
\hline & & Mean & Std. & Rank & Mean & Std. & Rank & Mean & Std. & Rank & Mean & Std. & Rank & Mean & Std. & Rank \\
\hline \multicolumn{17}{|c|}{ Districts } \\
\hline 1 & Ariyalur & 3.60 & 1.265 & 7 & 3.80 & 1.229 & 7 & 3.40 & 1.430 & 8 & 3.50 & 1.509 & 8 & 3.00 & 1.491 & 8 \\
\hline 2 & Cuddalore & 4.38 & 1.088 & 2 & 4.00 & 1.033 & 3 & 4.06 & 1.063 & 2 & 3.69 & 1.352 & 3 & 3.94 & 1.181 & 1 \\
\hline 3 & Nagapattinam & 4.13 & 1.088 & 3 & 4.31 & 1.014 & 2 & 4.13 & 1.204 & 1 & 3.63 & 1.204 & 5 & 3.69 & 1.250 & 4 \\
\hline 4 & Perambalur & 3.56 & 1.413 & 8 & 3.50 & 1.461 & 8 & 4.06 & 1.063 & 2 & 3.69 & 1.352 & 3 & 3.69 & 1.352 & 5 \\
\hline 5 & Thanjavour & 4.00 & 1.190 & 4 & 4.32 & 1.069 & 1 & 4.00 & 1.258 & 6 & 3.80 & 1.323 & 2 & 3.76 & 1.300 & 3 \\
\hline 6 & Thiruvannamalai & 3.92 & 1.176 & 5 & 3.88 & 1.191 & 5 & 4.04 & 1.122 & 5 & 3.50 & 1.216 & 7 & 3.42 & 1.442 & 7 \\
\hline 7 & Thiruvarur & 4.50 & .548 & 1 & 4.00 & 1.549 & 4 & 4.00 & 1.549 & 7 & 3.83 & 1.169 & 1 & 3.83 & 1.169 & 2 \\
\hline 8 & Villupuram & 3.73 & 1.208 & 6 & 3.80 & 1.091 & 6 & 4.05 & 1.180 & 4 & 3.61 & 1.316 & 6 & 3.57 & 1.421 & 6 \\
\hline \multicolumn{17}{|c|}{ Gender } \\
\hline 1 & Male & 3.95 & 1.186 & 2 & 3.94 & 1.199 & 3 & 4.05 & 1.186 & 1 & 3.71 & 1.224 & 5 & 3.72 & 1.282 & 4 \\
\hline 2 & Female & 3.86 & 1.203 & 3 & 3.95 & 1.113 & 1 & 3.94 & 1.176 & 2 & 3.54 & 1.366 & 4 & 3.44 & 1.423 & 5 \\
\hline \multicolumn{17}{|c|}{ Designation } \\
\hline 1 & Librarian & 3.95 & 1.196 & 3 & 4.04 & 1.143 & 2 & 4.07 & 1.174 & 1 & 3.74 & 1.230 & 4 & 3.69 & 1.298 & 5 \\
\hline 2 & Asst. Librarian & 3.78 & 1.166 & 3 & 3.83 & 1.098 & 2 & 4.33 & .840 & 1 & 3.33 & 1.414 & 5 & 3.50 & 1.505 & 4 \\
\hline \multirow[t]{2}{*}{3} & Others & 3.78 & 1.215 & 1 & 3.78 & 1.215 & 1 & 3.28 & 1.274 & 4 & 3.33 & 1.455 & 3 & 3.22 & 1.478 & 5 \\
\hline & Total & 3.91 & 1.190 & 3 & 3.94 & 1.162 & 2 & 4.01 & 1.179 & 1 & 3.64 & 1.281 & 4 & 3.61 & 1.343 & 5 \\
\hline
\end{tabular}

In the case of "Analytical skills" variable, the mean value range between 3.56 and 4.50 which indicate that the respondents' opinion leans between agree and strongly agree to the variables. The standard deviation ranges between 0.548 and 1.413 which indicates that there was no much deviation in respondents' opinion. The first three districts that prefer analytical skill were "Tiruvarur"; "Cuddalore" and "Nagapattinam". The least preferences were given by "Perambalur" respondents and it is followed by “Ariyalur" respondents.

"Relevant work experience" variable's mean value range between 3.50 and 4.32 which indicate that the respondents' opinion leans towards average and satisfactory. The standard deviation ranges between 1.014 and 1.549 which indicates that there were no much deviation in respondents opinion. The first three districts that prefer relevant work experience were "Thanjavur"; "Nagapattinam" and Cuddalore". The least preference was given by "Perambalur" respondents and it is followed by “Ariyalur” respondents.

Similarly in the case of "Updated knowledge" variable's mean value range between 3.40 and 4.13 which indicate that the respondents' opinion leans towards good and very good. The standard deviation ranges between 1.063 and 1.549 which indicates that there were no much deviation in respondents' opinion. The first three districts that prefer Communication skill were "Nagapattinam", "Perambalur" and Cuddalore". The least preference was given by "Tiruvarur" respondents and it is followed by “Ariyalur” respondents.

In the case of "Ability to understand, learn quickly and easily" variable, the mean value ranges between 3.50 and 3.83 which indicate that the respondents' opinion leans towards avarage to the variables. The standard deviation ranges between 1.169 and 1.509 which indicates that there was no much deviation in respondents' opinion. The first three districts that prefer Ability to understand learn quickly and easily were "Tiruvarur", “Thanjavur" and "Perambalur". The least preference was given by “Tiruvannamalai” respondents and it is followed by "Ariyalur" respondents.

"Novel approach and creativeness" variable's mean value range between 3.00 and 3.94 which indicate that the respondents opinion leans towards average and satisfactory The standard deviation ranges between 1.169 and 1.491 which indicates that there were no much deviation in respondents opinion. The first three districts that prefer Assessment skill were "Cuddalore"; "Tiruvarur" and "Thanjavur". The least preference was indicated by "Ariyalur" respondents and it is followed by "Tiruvannamalai” respondents. 


\section{Visible Vision}

The visible vision in work environment was ascertained in a five point scale such as Poor, Average, Satisfactory, Good and Very Good. The responses were compared between gender. The mean and standard deviation were calculated. The ranks were assigned based on mean and standard deviation. The responses gender-wise, mean, standard deviation and rank were shown in the Table 9.

Table 9: Visible Vision in Work Environment vs Gender

\begin{tabular}{|c|c|c|c|c|c|c|c|c|c|c|}
\hline S. No. & Gender & Poor & Average & Satisfactory & Good & Very Good & Total & Mean & Std & Rank \\
\hline 1 & Male & $\begin{array}{c}0 \\
(0.0)\end{array}$ & $\begin{array}{c}0 \\
(0.0) \\
\end{array}$ & $\begin{array}{c}7 \\
(4.5) \\
\end{array}$ & $\begin{array}{c}49 \\
(31.2) \\
\end{array}$ & $\begin{array}{c}38 \\
(24.8) \\
\end{array}$ & $\begin{array}{c}94 \\
(59.9) \\
\end{array}$ & 4.33 & .612 & 1 \\
\hline 2 & Female & $\begin{array}{c}0 \\
(0.0)\end{array}$ & $\begin{array}{c}0 \\
(0.0)\end{array}$ & $\begin{array}{c}7 \\
(4.5)\end{array}$ & $\begin{array}{c}33 \\
(21.0)\end{array}$ & $\begin{array}{c}23 \\
(14.6)\end{array}$ & $\begin{array}{c}63 \\
(40.1)\end{array}$ & 4.25 & .647 & 2 \\
\hline \multicolumn{2}{|c|}{ Total } & $\begin{array}{c}0 \\
(\mathbf{0 . 0})\end{array}$ & $\begin{array}{c}0 \\
(\mathbf{0 . 0})\end{array}$ & $\begin{array}{c}14 \\
(8.9)\end{array}$ & $\begin{array}{c}82 \\
(52.2)\end{array}$ & $\begin{array}{c}61 \\
(38.9)\end{array}$ & $\begin{array}{c}157 \\
(100)\end{array}$ & 4.30 & .625 & \\
\hline
\end{tabular}

The overall mean value works out to 4.30 which indicates that visible vision in work environment is good. The gender-wise mean value in the visible vision in work environment lies between 4.25 and 4.30 which indicates good. The standard deviation ranges between 0.612 and 0.647 which indicates that there has been no deviation in the respondents' opinion. The male has edge over female in the case of visible vision in work environment.

The mean value of visible vision on work environment among respondents of district, gender and designation were summarized and shown in the Table 10 and Figure 4.

Table 10: Visible Vision on Work Environment District, Gender and Designation-Wise

\begin{tabular}{|c|c|c|c|c|}
\hline \multirow{2}{*}{ S. No } & \multirow{2}{*}{ Districts } & \multicolumn{3}{|c|}{ Visible Vision } \\
\hline & & Mean & Std. & Rank \\
\hline \multicolumn{5}{|c|}{ Districts } \\
\hline 1 & Ariyalur & 4.32 & .639 & 3 \\
\hline 2 & Cuddalore & 4.21 & .658 & 8 \\
\hline 3 & Nagapattinam & 4.31 & .602 & 4 \\
\hline 4 & Perambalur & 4.30 & .675 & 5 \\
\hline 5 & Thanjavour & 4.38 & .619 & 2 \\
\hline 6 & Thiruvannamalai & 4.25 & .683 & 6 \\
\hline 7 & Thiruvarur & 4.24 & .597 & 7 \\
\hline 8 & Villupuram & 4.67 & .516 & 1 \\
\hline \multicolumn{5}{|c|}{ Gender } \\
\hline 1 & Male & 4.33 & .612 & 1 \\
\hline 2 & Female & 4.25 & .647 & 2 \\
\hline \multicolumn{5}{|c|}{ Designation } \\
\hline 1 & Librarian & 4.32 & .608 & 2 \\
\hline 2 & Asst. Librarian & 4.33 & .594 & 1 \\
\hline \multirow[t]{2}{*}{3} & Others & 4.11 & .758 & 3 \\
\hline & Total & 4.30 & .625 & \\
\hline
\end{tabular}




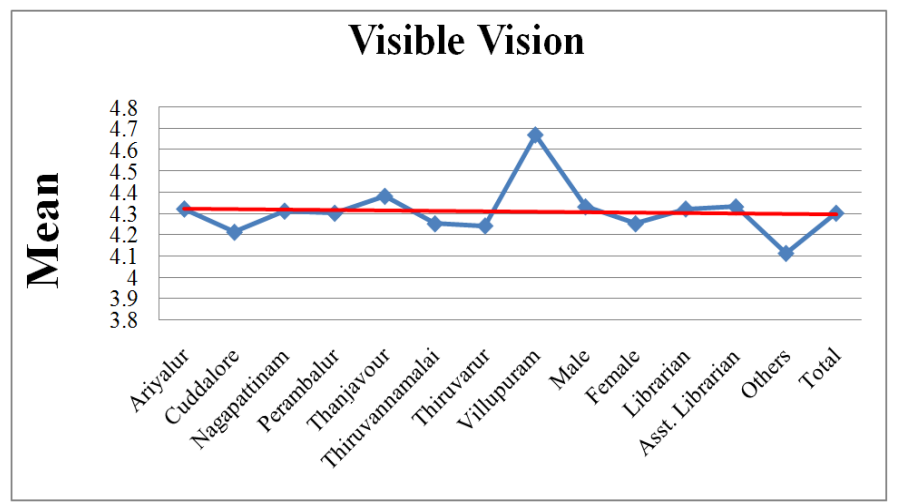

Figure 4: Visible Vision on Work Environment District, Gender and Designation-wise

It can be seen from the table 11 and figure 5, that mean value for visible vision on work environment were more than 4 which indicates that very good irrespective of district, gender and designation.

Table 11: Online Medium in Work Environment District, Gender And Designation-Wise

\begin{tabular}{|c|c|c|c|c|}
\hline \multirow{2}{*}{ S. No } & \multirow{2}{*}{ Districts } & \multicolumn{3}{|c|}{ Online Medium } \\
\hline & & Mean & Std. & Rank \\
\hline \multicolumn{5}{|c|}{ Districts } \\
\hline 1 & Ariyalur & 2.82 & .815 & 3 \\
\hline 2 & Cuddalore & 2.71 & .751 & 7 \\
\hline 3 & Nagapattinam & 2.94 & .998 & 1 \\
\hline 4 & Perambalur & 2.80 & .789 & 5 \\
\hline 5 & Thanjavour & 2.81 & .834 & 4 \\
\hline 6 & Thiruvannamalai & 2.75 & .775 & 6 \\
\hline 7 & Thiruvarur & 2.84 & .850 & 2 \\
\hline 8 & Villupuram & 2.67 & 1.033 & 8 \\
\hline \multicolumn{5}{|c|}{ Gender } \\
\hline 1 & Male & 2.79 & .815 & 2 \\
\hline 2 & Female & 2.83 & .834 & 1 \\
\hline \multicolumn{5}{|c|}{ Designation } \\
\hline 1 & Librarian & 2.81 & .840 & 2 \\
\hline 2 & Asst. Librarian & 2.72 & .826 & 3 \\
\hline \multirow[t]{2}{*}{3} & Others & 2.83 & .707 & 1 \\
\hline & Total & 2.80 & .820 & \\
\hline
\end{tabular}

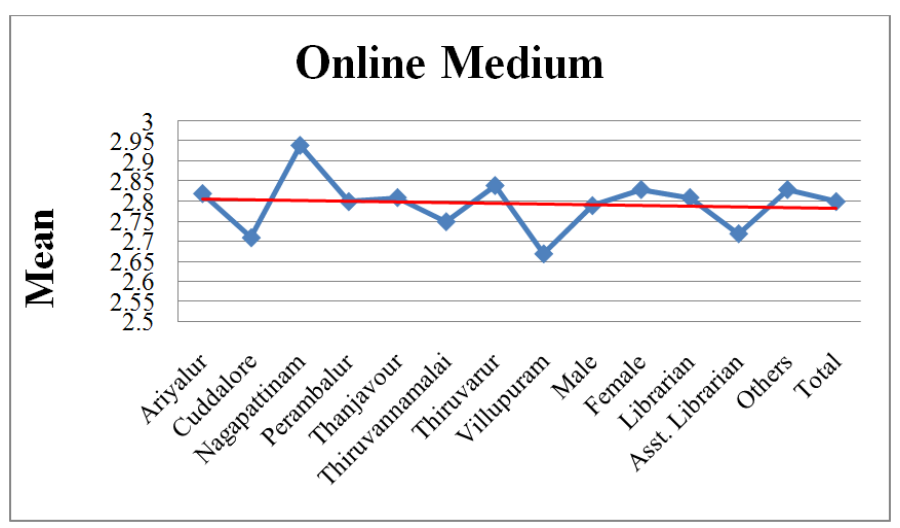

Figure 5: Online Medium in Work Environment District, Gender and Designation-wise 
It can be seen from the table 11 and figure 5, that mean value for Online medium in work environment were more than 2.8 which indicates very good irrespective of district, gender and designation.

It can be inferred that the online medium in work environment may be one of the factor for capability building.

\section{CONCLUSIONS}

A small set of skills is overwhelmingly more "in demand" for current and future professionals. Core skills, especially in communication, integration, and presentation, are overwhelmingly desirable among professionals in 2020. The skills today's professional need for tomorrow's positions are specific and important across a common set of high-growth/high-salary occupations.

- Communicate by posing and responding to questions that probe reasoning and evidence (These skills include listening for a full range of opinions on a topic or issue; responding thoughtfully to diverse perspectives; synthesizing comments, claims, and evidence made on all sides of an issue; and determining what additional information or research is required to complete the task.)

- Integrate/synthesize multiple sources of information into a coherent (understanding to make informed decisions and solve problems, evaluating the credibility and accuracy of each source Summarize, represent, and interpret data to form an opinion and defend a (position, including the ability to make inferences and draw conclusions from observations, surveys, and experiments

- Use probability to evaluate outcomes of decisions

- Present information, findings, and supporting evidence, conveying a clear and distinct perspective, including the appropriate use of digital media (e.g., textual, graphical, audio, visual, and interactive elements) enhance understanding of the findings, reasoning, and evidence

\section{REFERENCES}

1. Pinto Molina Maria (2008) Cyber abstracts: A Portal on the Subject of Abstracting Designed to Improve Information Literacy Skills: Journal of Information Science 34(5): 667-679.

2. Walker A Stephanie (2008). Computer-assisted library instruction and face-to-face library instruction prove equally effective for teaching basic library skills in academic libraries. Evidence Based Library and Information Practice 3(1):57-60.

3. Dell -Price, Carol and Cotton Yvonne (2008).Assessing Information literacy skills within a core module ALISS Quarterly $3(3): 31-33$

4. Ramesh babu B (2011). Information Literacy skills for LIS Professionals. In: National Conference on Information Literacy Skills for college Librarians in Digital Environment. New Dellhi: Vayu Education of India.pp.3-16.

5. Ramesh babu B and Nageswara Rao P (2011). Competencies and Skills for LIS Professionals in the context of Information Literacy and Digital Literacy. IN: National Conference on Information Literacy Competencies for Higher Learning and Research organised by Tumkur University (Proceedings). Bangalore: Indian Academic Library Association pp.254-262.

6. Haglund Lotta and A Herron David (2008). Students with non-proficient information seeking skills greatly over-estimate their abilities. Evidence Based Library and Information Practice 3(2): 48-51.

7. Thomas Peter and Ruttert Paul M. (2008). A Computer Literacy Skills Profile of Pharmacists Residing in Two Counties of England Health Information and Libraries Journal 25(4): 288- 294. 
8. Owei Vesper; Bada Abiodun O. and Aniebonam Manny (2006). Addressing the information technology skills shortage in developing countries: tapping the pool of disabled users. Journal; of Information Communication and Ethics in Society 4(2):77-89.

9. Harris Lesley Ellen (2007). When the negotiations begin listen carefully stay on point. Information Outlook 11(3): 32-33.

10. Bergman, T. (1992), “Preparing to Enter and Succeed in Human Resource Management," SAM Advanced Management Journal (Winter 1992):37.

11. Kaufman, B.E. (1994), What companies want from HR graduates, HR Magazine, September, 84-86

12. Sherman, A., Bohlander, G. and Snell, S. (1998), Managing Human Resources, 11th ed, Cincinnati, Ohio: South-Western College Publishing.

13. Sanghi, S. (2004), The Handbook of Competency Mapping, Understanding, Designing and Implementing Competency Models in Organizations, New Delhi: Response Books (A division of Sage Publications India Pvt Ltd).

14. Deb, T. (2006), Strategic Approach to Human Resource Management, Concept, Tools and Application, New Delhi: Atlantic Publishers \& Distributors.

15. Hariharan, S., \& Tamizhchelvan, M. (2016). Ethics of Library Professionals' Relation with Organisation and Professionalism in Self Financing Engineering College Libraries in Tamilnadu. International Journal of Library Science and Research (IJLSR), 6(3), 33-38.

16. Opatha, H. H. D. N. P. (2007), Competencies as Human Assets: A Perspective, Sri Lankan Journal of Human Resource Management, Vol. 2, No.1, pp.1-13.

17. Opatha, H. H. D. N. P. (2009), Human Resource Management: Personnel, Colombo: Department of HRM, University of Jayewardenepura.

18. Balakrishnan et al., (2014), Human Relation Skills among the Library and Information Professionals in Higher Educational Institutions In and Around Chennai Journal of Advances in Library and Information Science ISSN: 2277-2219 Vol. 3. No.3. 2014. Pp264-274 